\title{
System dynamics modelling of bread waste problem
}

\section{Atık ekmek probleminin sistem dinamiği yöntemi ile modellenmesi}

\author{
Elvan GÖKALP1* (iD)
}

1Warwick Manufacturing Group, The University of Warwick, Coventry, United Kingdom. elvan.gokalp@warwick.ac.uk

\section{Abstract}

Bread waste is a significant economic and environmental problem for many countries. In this paper, we propose a system dynamics approach for bread waste problem that involves significant complexities such as feedbacks and dynamic elements. System dynamics modelling is a simulation method that allows to model these complexities and investigate the impact of public policies on the system performance. We develop a system dynamics model of bread production and consumption dynamics within a geographical area. We design numerous computational experiments by using the related data from Istanbul, Turkey. The experiments suggest that the shelf life is the most important factor on the waste production: doubling the shelf life of the bread can reduce the bread waste by $25 \%$.

Keywords: System dynamics modelling, Food waste prevention, Bread supply chain.

\section{Introduction}

Global warming threatens the world more than ever. According to the recent report of UN [1], only 12 years are left to reduce the speed of global warming; otherwise, the world will face unrecoverable changes. An important contributor of the global warming is food waste; $20 \%$ of greenhouse gas emissions in the world is due to the agricultural activities [2]. Better management of the food redistribution and consumption can decrease the greenhouse gas emissions from agriculture by $14 \%$ [2].

Other than environmental problems, the food waste creates a significant monetary loss. The monetary value of the food waste in the world is around $\$ 750$ billion. The percentage of the food waste on Canadian GDP is $2 \%$ and accounts for the sum of the GDPs of the poorest 32 countries in the world [3]. USA generates the largest food waste rate in the world with $40 \%$ [4]. In Germany, around $12 \%$ of the food and non-alcoholic beverages is wasted at 2010 [5]. Among many components of food waste, bread constitutes around $10 \%$ in the UK [6], 20\% in Netherlands [7], Austria [8], and US [9], and 5\% in Turkey. The percentage of the wasted bread among all bread production is $36 \%, 30 \%, 19 \%, 8-10 \%$, respectively, in the UK [10] in Iran [11], in Italy [12] and in Germany [13].

The main cause of the bread waste is the inadequate management of food supply chain. A food supply chain can be defined as the processes that describe how food from a farm ends up on our tables. This chain comprises of production,
Öz

Ekmek israfi pek cok ülke için önemli bir mali ve cevresel sorun oluşturmaktadır. Bu problem, içinde pek çok geri besleme döngüsü içeren, dinamik ve karmașık bir sistem problemidir. Bu çalıșmada ekmek israfının oluşumu sistem dinamiği yöntemiyle analiz edilmiștir. Sistem dinamiği yöntemi geri besleme döngüleri içeren dinamik problemlerin modellenmesine ve analiz edilmesine olanak sağlayan bir yaklașımdır. Bu çalıșmada sunulan model, ekmek üretim ve tedarik zincirinin çesitli așamalarını kapsamaktadır. Olusturulan model farkl parametre değerleri ve gelecek senaryoları altında test edilmiş, sonuçar analiz edilmiștir. Simulasyon senaryolarında İstanbul șehrine ait veri seti kullanılmıștır. Senaryo sonuçları ekmek israfinın önlenmesinde en önemli faktörün ekmeğin raf ömrü olduğunu göstermiștir. Ekmeğin raf ömrünün iki katına çıkarılmasının ekmek israfinı \%25 oranında azaltabileceği bulunmuștur.

Anahtar kelimeler: Sistem dinamigi modellemesi, Atık yiyecek önleme, Ekmek tedarik zinciri.

processing, distribution, consumption and disposal. The level of the waste varies from one stage of the food supply chain to the other based on the crop production method, social and cultural characteristics, or economic development level. Since we focus on bread waste, we only consider the stages after its ingredients are processed, i.e. after a bread is produced.

The bread waste prevention is a complex problem that involves interacting forces and dynamics such as consumption rate and food availability. These dynamics generate feedback loops and non-linearity that are very difficult to analyse and understand with traditional simulation and mathematical modelling methods. Thus, we model the bread waste prevention problem by using system dynamics (SD) approach that is suitable for complex systems involving feedbacks. We model the bread consumption in household and non-household entities as well as production and storage activities in bakeries. Although the bread waste is also an environmental problem, we only focus on its economic aspects in this study.

We use the data from Turkey for the computational experiments due to this country's divergent characteristics in terms of the bread production and consumption. First of all, bread is still baked by small local enterprises in Turkey. Secondly, the price and size of the bread are set by the negotiations between the bakery association and the government based on the costs of production and macroeconomic indicators. Therefore, the power of the free market forces to regulate the balance between production and consumption is inhibited. As a result, a significant amount of bread ( $10 \%$ of all bread production) is wasted in bakeries

${ }^{*}$ Corresponding author/Yazışılan Yazar 
(around $50 \%$ of the waste), households (around 30\% of the waste) and non-household consumers such as restaurants, hotels, school cafeterias, etc. [14].

Another characteristic of Turkey is the high rate of unregistered bakeries that do not pay for taxes. The rate of these bakeries vary between $2 \%$ to $30 \%$ in different cities [15]. Due to a lower production cost, the unregistered bakeries can generate higher revenues and can sell more than the registered ones. Therefore, they increase total sales and waste. Finally, the breads are usually not sold in bags in the bakeries which reduces the shelf life of the bread and results in more weathered and wasted breads.

Although we use Turkey as the base case, the model can be applied to other countries with small modifications or additional experiments. For example, if the model would be applied to UK, since the breads are sold in bags in this country, the shelf life parameter can be increased. Alternatively, the model can be modified to allow the market forces to determine the bread price. We analyse such a case in the computational experiments.

Next section, first, provides a brief introduction of system dynamics methodology. Then, it presents the related literature on food waste, food supply chains, and system dynamics applications on these issues. Sections 3 and 4 introduce the problem and present the SD model. Afterwards, we show the results of the computational experiments that investigate the efficacy of several waste prevention strategies.

\section{Literature review}

SD is a simulation modelling approach that assists in modelling complex systems and their dynamic behaviours [16]. One of the complexities of a system is the relationships and feedback loops between variables. A cause-effect diagram, showing the causal relationships between model variables, is helpful to capture these complexities. However, the quantitative aspects of variables would be better represented with a stock-flow diagram that is essential part of a SD model. In a stock-flow diagram, stocks represent the entities that accumulate over time. On the other hand, the flows are the changes in the stocks. The details of the SD approach can be found in [16].

Among many others, SD has been used for treatment management [17], hospital flow modelling [18], and semiconductor industry development [19]. In terms of waste related problems, it has been used for the management of hospital waste [20], construction waste [21] or municipal environmental policies [22]. These studies concentrate on the management of waste generated out of some commercial or medical activities. On the other hand, we mostly focus on policymaking for the prevention of bread waste.

In the literature, food supply chain systems have been studied quite intensely. For a review of quantitative modelling of food supply chain systems, reader is referred to [23]. Among different quantitative approaches, simulation modelling has been applied to food supply chain design [24] and distribution network design for pasta [25]. Specifically, Reiner and Trcka [25] analyse the impact of a distribution centre between production and retail centres considering different demand patterns. Van Der Vorst et al. [24] develop a discrete event simulation model to test the impact of different distribution networks on food quality, cost, energy use and emissions.
SD has been used by researchers to analyse supply chain and logistic problems [26]. Among these, few focus on food supply chains. Georgiadis et al. [27] model a generic food supply chain and consider the capacity planning problem. Their study applies the proposed approach to a Greek fast-food restaurant. Another paper focusing on food supply chains is [28] which presents a generic SD model for a chicken supply chain. As the main difference from these papers, our study models the demand as well as the production side of the supply chain that is very critical on the overall dynamics of the system and waste generation in particular. Additionally, our paper comprises of extensive computational experiments to analyse and investigate the impact of several waste prevention policies.

\section{Problem description}

This section gives the details of the bread waste prevention problem. We consider a certain geographical area such as a city or district that has a number of bakeries with an average number of breads produced each day. The household members or non-household entities buy breads from the bakeries or stores based on the number of breads that they currently have and their average bread consumption. Note that we use stores and bakeries interchangeably in the paper. The unsold breads stay in the shelf until the end of their shelf life. Otherwise, they are considered as waste and taken off from the shelves. Part of the breads bought by household and non-household entities are consumed based on a normally distributed consumption level. The rest of the purchased bread has a chance of consumption on the following days until the end of their shelf life. The cause-effect diagram of the problem is shown in Figure 1.

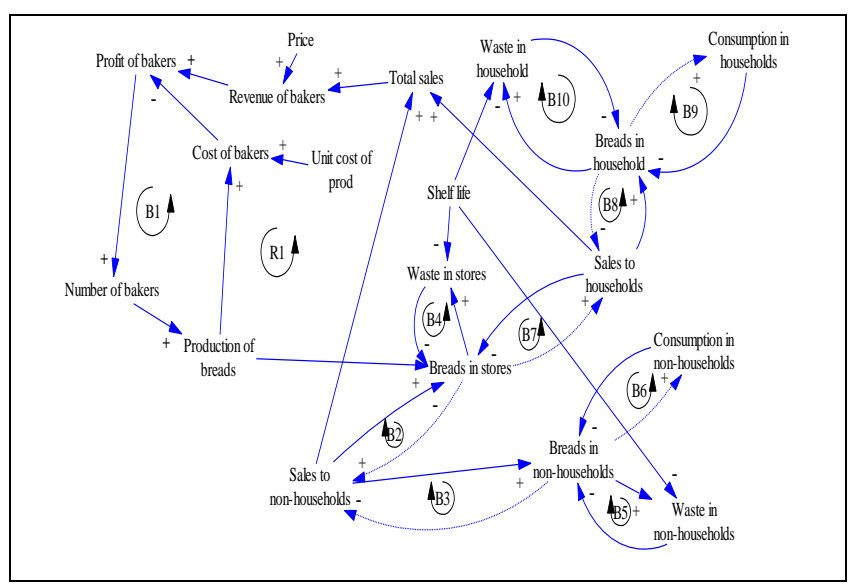

Figure 1. Cause-effect diagram of the bread waste problem.

The arrows represent the relationship between variables: a positive (negative) signed arrow from $\mathrm{X}$ to $\mathrm{Y}$ indicates that either $\mathrm{X}$ adds to (subtracts from) $\mathrm{Y}$, or a change in $\mathrm{X}$ produces a change in $\mathrm{Y}$ in the same (negative) direction. The problem consists of several feedback loops shown with half circles and letters inside. A feedback loop shows a cycle of variables affecting each other. A positive feedback loop (with an R sign) indicates that it contains an even number of negative causal links. In a positive feedback loop, a change leads to a further change, suggesting the presence of an unstable equilibrium. On the other hand, a negative feedback loop (with a B sign) generates a contradicting effect and balances the system.

Some variables have a partial relationship that becomes relevant under some conditions. For example, breads on stores do not directly define sales but when breads in stores decrease 
below a critical level, the sales drop. We present a partial effect between two variables with a dashed line.

The problem has ten negative (balancing) and one positive (reinforcing) feedback loop. The feedback loops B2-10 only involve two variables and do not dominate the whole system. On the other hand, the feedback loops B1 and R1 involve many variables and affect the behaviour of the system significantly. B1 is the balancing effect of the market on the bread production. Namely, as there are more production, the profits drop and the production decreases at the end. The feedback loop R1 involves the bread production, breads in stores, sales to households, revenue and profit of the bakers. As the bread production increases, the sales increases which leads to more revenue and profit for the bakers that positively affect the production.

\section{Model description}

The model is implemented in Vensim PLE®, a SD modelling software. There are three main sectors in the model: bakeries, households and non-households. The first sector, bakeries, has three stocks: "number of bakeries", "breads in stores", and "revenue of bakeries". "Number of bakeries" has an inflow called "new bakeries", and an outflow called "bakery closures". The level of "new bakeries" are affected by the "number of bakeries" and "the effect of profits on new bakeries" that is defined as a graphical function. First, we formulate "extra profit per baker" as:

$$
\begin{gathered}
\text { (usual profit per baker - profit per baker)/ } \\
\text { usual profit per baker, }
\end{gathered}
$$

where "usual profit per baker" is a constant computed as the difference between the unit production cost and selling price of the bread. "Profit per baker" is computed as "total profit" divided by the number of bakeries.

The other flow "bakery closures" is also affected by the "number of bakeries" and "the effect of profits on closures". The other stock, "revenue", has an outflow "cost of production" that is computed by multiplying the "production" amount with "unit cost of production". The inflow to the revenue stock is computed by multiplying total sales with the unit price. The difference between the revenue and cost of production is then defines the level of total profit that is used on the computation of profit per baker. Note that we do not model each bakery as an individual entity as that would require a different simulation methodology such as discrete-event simulation. Alternatively, we aggregate all bakeries and assume that they face the average unit production cost. Also, "stores" represent all entities where bread is sold to consumers.

The second stock, "breads in stores" has one inflow called "production" and three outflows "store waste", "household sales" and "non-household sales". Store waste level depends on the delay of "production" amount by the shelf life and total sales that is the sum of "household and non-household sales".

The second and third sectors that consist of household and nonhousehold activities have two main stocks: "household breads" and "non-household breads". The activities of these two entities (household and non-household) are the same, except the levels of parameters. Therefore, we only explain the household sector here. The "household bread" stock has one inflow called "household sales". The level of "household sales" is affected by the "household consumption usual" that is a normally distributed parameter with a mean "average household consumption usual".
Also, "household sales" are increased if household stock drops. This relationship is defined as a graphical function of household stock rate computed as:

\section{(Household usual - household)/ Household usual.}

Note that bread waste amount can be modelled by two different ways. The first one is to delay the production by the shelf life and to deduce the sales from this delayed level. The other way of modelling is to create additional stocks representing oneday-old and two-days-old breads (assuming a shelf life of 2 days) and then taking off the consumption from these stocks. We found that these two ways of modelling result in the same waste levels. The rest of the model formulations and the Vensim model are provided as supplementary materials.

\subsection{Model validation}

Before the computational experiments, we need to ensure that the model is a good enough representation of the reality (model validation). Two main tests are conducted to ensure the validity of the model: direct and indirect structure tests that are part of the model validation step in the SD approach [29].

First, we conduct some direct tests such as unit consistency without any simulation runs [29]. The unit consistency test is conducted by entering the units of its input variables and ensuring that the units of variables match appropriately.

Indirect structure (structure-oriented behaviour) tests are conducted to compare the behaviour of the model with the (expected) real life behaviour in some extreme or other special condition simulations. In the first test, all stocks were held in their equilibrium levels [29]. The aim behind this test is to assure that the system has a balanced structure. In the second part of the indirect structure tests, the system behaviour under extreme conditions was examined. Each of these extreme cases is designed as simulation scenarios and the results are investigated to understand whether the model gives reasonable results under these extreme scenarios [29].

\section{Computational experiments}

\section{$5.1 \quad$ Input data}

We use the data from Istanbul in Turkey for the computational experiments. Istanbul contains around a quarter of Turkey's population and has a very large rate of unregistered bakeries (around 30\%) that creates an even larger waste. The time unit of the simulation is one day while the simulation period is 2000 months. The parameter levels as well as the sources of information are shown in Table 1.

Table 1. Input data and corresponding sources of information.

\begin{tabular}{ccc}
\hline Parameter & Level & Source \\
\hline Rate of unregistered bakers & 0.3 & {$[30]$} \\
Average production per store & 3500 & {$[31]$} \\
Total consumption & $18 \mathrm{M}$ & {$[32]$} \\
Unit cost of production & 0.8 & {$[32]$} \\
Price & $1.25 \mathrm{TL}$ & {$[30]$} \\
Shelf life & 2 days & {$[33]$} \\
Average and standard & $4 \mathrm{M} \mathrm{\&}$ & Expert opinion \\
deviation of household & 200 & \\
consumption usual & & \\
Average and standard & $12 \mathrm{M} \mathrm{\&}$ & Expert opinion \\
deviation of non-household & 600 & \\
consumption usual & & \\
Min. household sales & $1.5 \mathrm{M}$ & Expert opinion \\
Min. non-household sales & $6 \mathrm{M}$ & Expert opinion \\
\hline
\end{tabular}




\subsection{Base Run}

After the validation step, the model is run for 2000 months that is long enough to investigate the dynamics of the underlying system. The dynamics of the important indicators in the base case are shown in Figures 2 and 3.

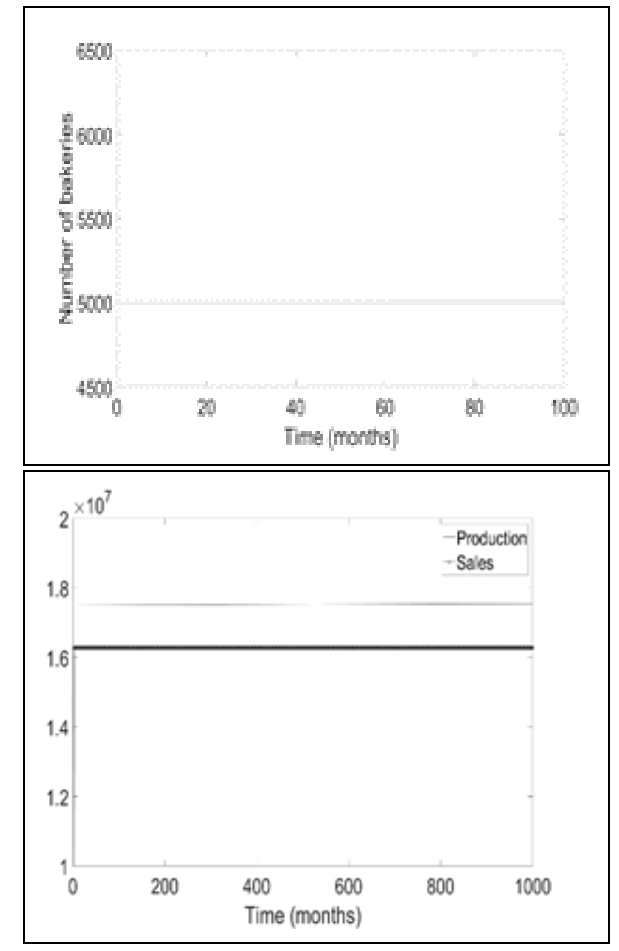

Figure 2. Number of bakeries, production and total sales in the base run.

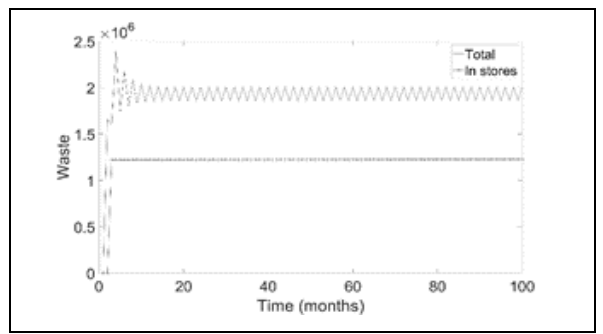

Figure 3: Wastes from different stakeholders in the base run.

The results show that the indicator levels become stable after around $15^{\text {th }}$ month. This period can be seen as the warm-up of the simulation to reach the stability [34]. Total waste level is around $2 \mathrm{M}$ during the run that is very close to the real level of the bread waste in Istanbul [35]. The model predicts the percentage of waste out of bread production in bakeries as $10.8 \%$ on average while this variable is around $10 \%$ in real-life [36]. These observations indicate that the model is a good approximation of the real system.

We observe that the waste levels oscillate during the simulation period that is possibly due to the delay on the effect of bread stocks on the consumption level. Because of the numerous negative feedback loops in the problem, we do not observe an ever increasing or decreasing behaviour but rather a stable model output. The only positive feedback loop, R1, do not have a significant effect on the outputs probably because the (partial) positive relationship between the breads in stores and sales to households is not activated. This inactivation is due to breads in stores not falling below the critical levels. The positive feedback loop may become active in scenario experiments depending on the parameter levels. On the other hand, the negative feedback loop, B1, dominates the model output and contributes to the stable behaviour generated by other negative feedback loops.

\subsection{Scenario analysis}

The scenario analysis investigates the impact of waste prevention policies and several input parameters, such as production costs, on the waste levels. During the runs, we only vary the levels of the related variables while all other variables are kept in their base run levels.

\subsubsection{Effect of graphical functions for new and closed stores}

Note that the effect of profits on store openings/closures depend on the strength of the entry barrier for the bread market in the country. For example, the bakery association in Turkey suggests to have a fixed amount of bakeries in neighbourhoods to prevent new bakeries. We test the impact of such a scenario under an extreme condition where opening and closing of bakeries are not allowed. This scenario also corresponds to the case where the graphical functions for effect of profit on bakery openings/closures are assumed to be zero. Total waste in the base run and when bakery openings and closures are not allowed is shown in Figure 4.

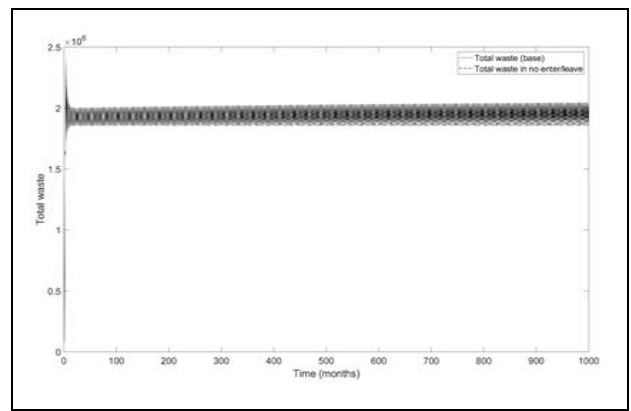

Figure 4: Total wastes in the base run and when new or closed bakeries are not allowed.

As the figure shows, there is no difference on total wastes in both cases. We observed the same phenomenon in other indicator levels such as production or sales amounts. Therefore, the results indicate that the graphical functions for market entry/leave do not have significant effect on the waste levels.

\subsubsection{Effect of price dependency}

The bread prices may go up or down depending on the macroeconomic conditions. This test investigates the effect of bread price on the waste generation. For this purpose, we assume that the demand has a non-linear relationship with the price [37]. The graphical function that defines this relationship is presented in Figure 13 in Appendix. We vary the price between $1 \mathrm{TL}$ and 1.5 TL (the level in the base run is $1.25 \mathrm{TL}$ ) and observe that when the price is $1 \mathrm{TL}$, the number of stores decreases significantly and the breads in the bakeries deplete. Obviously, this is an extreme condition and shows that the price should be higher than a certain level to keep the variable levels stable. This extreme result can be due to the financial loss of the bakeries as the price drops below a certain level. Total wastes in three different price levels (1.5 TL, 1.25 TL - base, and 1.1 TL) are presented in Figure 5. Due to the difficulty on observing the dynamics, we provide the same results with a shorter time horizon in the same figure. 


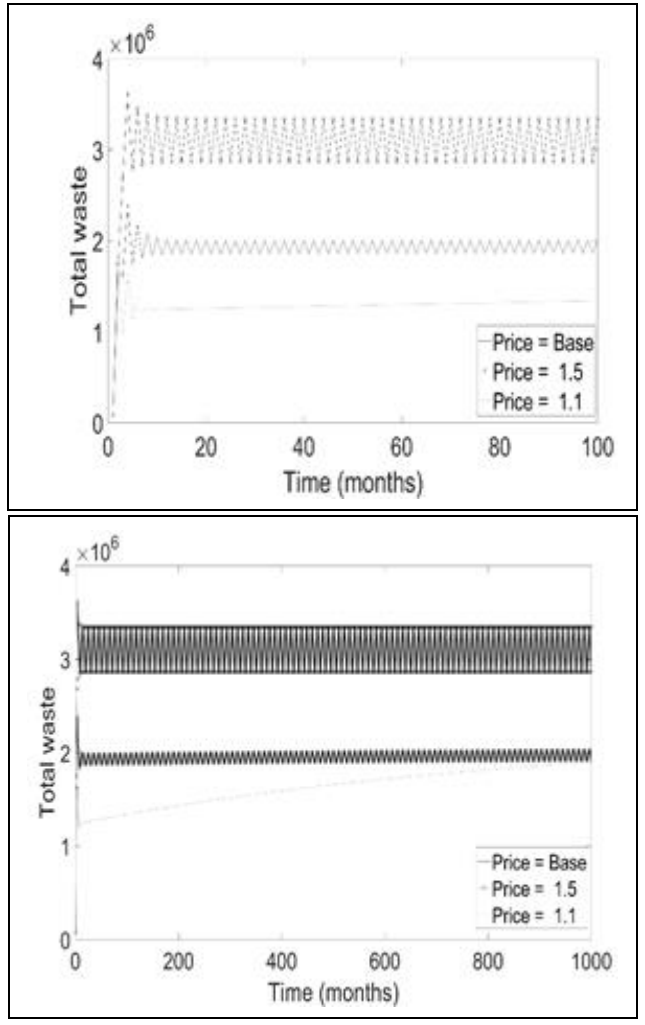

Figure 5. Total waste in different bread prices with a shorter (left) and longer time horizon (right).

Total waste is higher when the bread price is increased. This shows that a higher price does not necessarily result in a decrease in the waste. This counter-intuitive result can be explained by increased incentives for the bakeries to produce more. On the other hand, total waste levels when the prices are 1.1 TL and 1.25 TL, are the same at the end of simulation which indicates that the price does not have a linear effect on the waste level. Another observation is that the oscillation around the waste is higher with larger price. This may be due to the delayed effect of the higher bread production.

\subsubsection{Effect of price and production cost}

The previous experiment assumes that the production cost stays the same in different scenarios. An alternative scenario is that the price is increased due to a higher production cost i.e. higher oil prices or a lower harvest volume of wheat. In this test, we assume that the price and the unit production cost increase by the same amount. In other words, the unit profit is kept the same in all scenarios. We test the effect of this case by assuming that the prices are the same as the previous scenario $(1.5 \mathrm{TL}$, 1.25 TL, and $1.1 \mathrm{TL}$ ) and the production costs are $1 \mathrm{TL}, 0.75 \mathrm{TL}$, and $0.6 \mathrm{TL}$, respectively, for each scenario. Total wastes in these scenarios are shown in Figure 6 for different time horizons.

We observe an interesting phenomenon in this experiment: the variation around total waste when price is $1.5 \mathrm{TL}$ decreases significantly, as well as the average total waste. Also, the waste is lower when the price $1.1 \mathrm{TL}$ compared to that in the base case during most of the simulation period. The results indicate that the price should be adjusted accordingly when there is any change in the unit production cost. We find that the waste rate in stores is increased with a higher price. This may indicate that the price increase has not affected the production rate but decreased the consumption level.

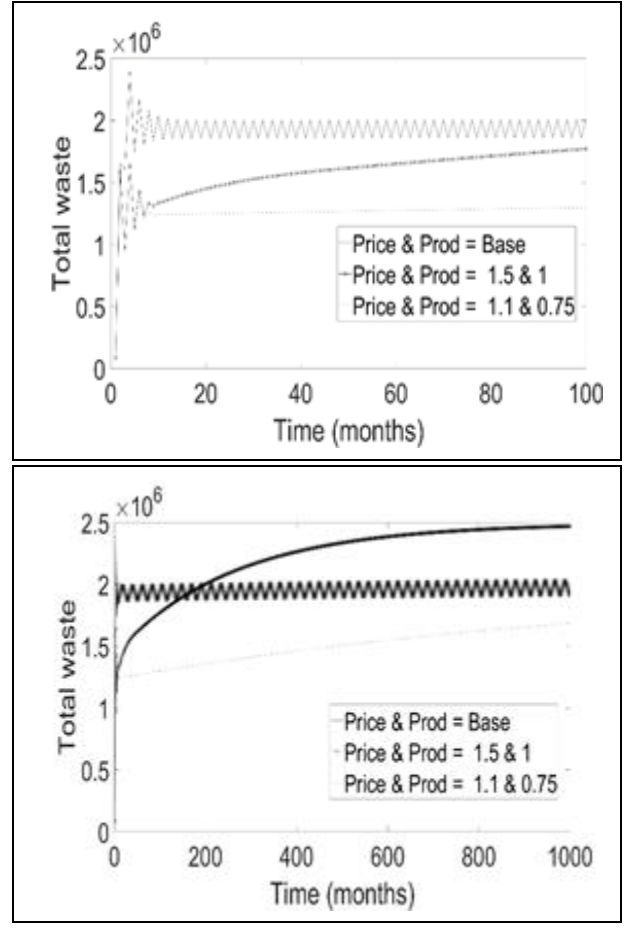

Figure 6. Total waste in different time horizons for different prices and production cost levels.

\subsubsection{Effect of production cost}

As mentioned previously, the unit production cost depends on the oil prices, harvest volumes, or electricity/gas prices. This experiment investigates the effect of unit production cost on the waste levels. For this purpose, we simulate two scenarios where the unit production costs are $0.95 \mathrm{TL}$ and $0.45 \mathrm{TL}$, respectively, while all other parameters are in their base levels. Since the variation of waste inhibits to see the difference clearly, we provide Figure 7 that shows the average total wastes (over the simulation period) in three unit-production costs. When the production cost is $0.45 \mathrm{TL}$, average total waste does not change significantly (only $2 \%$ decrease) compared to the base case. When the unit production cost is $0.9 \mathrm{TL}$, average total waste is $9 \%$ higher than the base case. Note that the profit per bakery directly depends on the production cost. Therefore, the profit per baker is also lower than the base case when the unit production cost is $0.9 \mathrm{TL}$. However, the decrease in the profit is lower for the unregistered bakeries. Therefore, they result in more production and waste. The results indicate that when the production cost increases, the government should take an action to prevent an increase in the waste level.

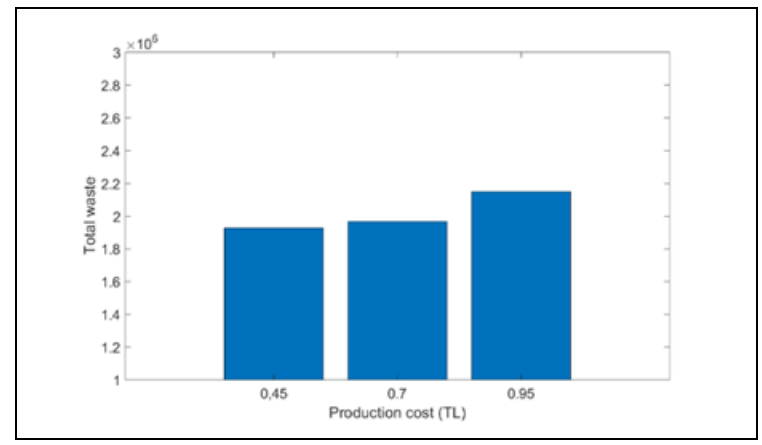

Figure 7. Average total waste in different unit production costs. 


\subsubsection{Effect of Unregistered Bakers}

A significant problem in the bread supply chain is the unregistered bakers that can produce bread for a lower cost compared to the others. The rate of unregistered bakers can be reduced with stricter policies and higher penalties. In this test, we examine the impact of unregistered bakery rate on the waste level. For this purpose, we vary the unregistered bakery rate between 0 and 1 and provide total wastes and the rate of waste in bakers in Figure 8 for unregistered baker rate of $0,0.3$ (base) and 0.6, as an example.

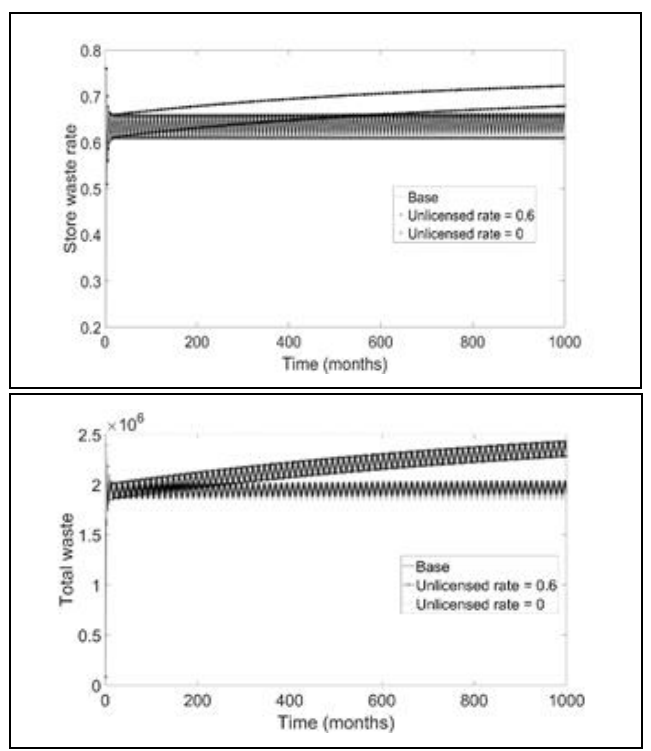

Figure 8. Total wastes and waste rate in bakeries in different unregistered bakery rates.

Note that, to make the comparison clearer, we run this experiment with deterministic household and non-household consumptions (i.e. the variance of the demand distributions is assumed to be zero). The average waste during the simulation with high unregistered bakery rate is 30\% larger than that in the base case. On the other hand, we observe that a very small unregistered bakery rate results in $11 \%$ smaller waste than the base case.

\subsubsection{Effect of shelf life}

A possible prevention method for bread waste is to increase the bread's shelf life. The shelf life can be increased by better packaging and preserving methods. We investigate the effect of such a policy by running the model for a shelf life of 4 days instead of 2 days as in the base case. Total wastes in two scenarios are shown in Figure 9. For the sake of clarity, the outputs are presented for the first 200 months of the simulation.

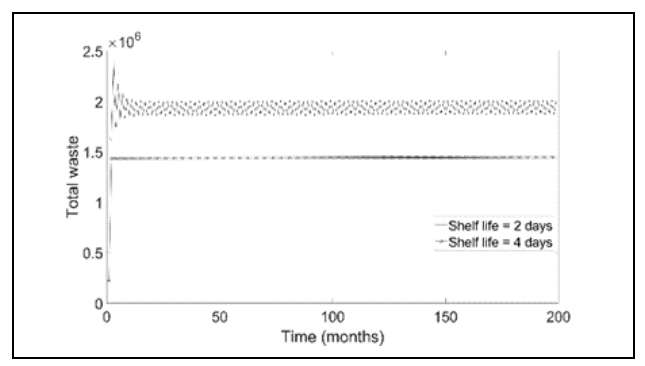

Figure 9. Total waste in different shelf lives.
The figure indicates that total waste can be reduced by $25 \%$ on average if the shelf life is doubled. Also, a higher shelf life results in a lower variation around the total waste.

\section{Conclusion}

Food waste is a serious threat and a major driver of global warming. Bread, as one of the fundamental consumer food, is a significant contributor of the food waste. This paper presents a SD approach to analyse the bread waste problem and test the impact of several prevention policies on the bread waste. The model considers the related activities of the producers, sellers and consumers of bread.

We use the data of Istanbul as a case study in the computational experiments. We specifically test the impact of bread price, unit production cost, unit profit, rate of unregistered bakeries and shelf life on the waste levels. The experiments show that a higher unit production cost does not result in a lower waste level. The second observation from the experiments is that closing all unregistered bakeries would decrease the waste by $11 \%$. Finally, the experiments show that doubling the shelf life of the bread can save $25 \%$ of the waste. In the future studies, the model can be expanded to investigate the impact of bread size and different types of breads on the waste generation.

\section{References}

[1] Intergovernmental Panel of Climate Change. "Global Warming of $1.5 \mathrm{C}$ ". World Meteorological Organization, Geneva, Switzerland, 2018.

[2] Hiç C, Pradhan P, Rybski D, Kropp JP. "Food surplus and its climate burdens". Environmental Science \& Technology, 50(8), 4269-77, 2016.

[3] Value Chain Management Centre. "The Cost Of Canada's Annual Food Waste". Toronto, Canada, 2014.

[4] Goldenberg S. "Half of All US Food Produce is Thrown Away, New Research Suggests". https://www.theguardian.com/environment/2016/jul/1 3 /us-food-waste-ugly-fruit-vegetables-perfect) (12.07.2018).

[5] Kranert M, Hafner G, Barabosz J, Schuller H, Leverenz D, Kölbig A, Schneider F, Lebersorger S, Scherhaufer S. "Ermittlung der Weggeworfenen Lebensmittelmengen und Vorschläge zur Verminderung der Wegwerfrate bei Lebensmitteln in Deutschland". http://www.bmelv. de/SharedDocs/Downloads/Ernaehrung/WvL/Studie_Le bensmittelabfaelle_Langfassung. pdf, (10.05.2018).

[6] Waste and Resources Action Programme (WRAP). "Estimates of Food Surplus and Waste Arisings in the UK". London, UK, 2017.

[7] Thönissen R. "Food waste: The Netherlands". EU Presidency Climate Smart Food Conference, Lund, Sweeden, November, 2009.

[8] Parfitt J, Barthel M, Macnaughton S. "Food waste within food supply chains: quantification and potential for change to 2050". Philosophical Transactions of the Royal Society B: Biological Sciences, 365(1554), 3065-3081, 2010.

[9] Jones T. "The value of food loss in the American Household". Bureau of Applied Research in Anthropology, A Report to Tilia Corporation, San Francisco, CA, USA, 2004.

[10] Waste and Resources Action Programme (WRAP). "Household food and drink waste in the UK". Banbury, UK, 2009. 
[11] Amid J. "The dilemma of cheap food and self-sufficiency: The case of wheat in Iran". Food Policy, 32(4), 537-552, 2007.

[12] Fattibene D, Bianchi M. "Fighting against Food Losses and Waste: An EU Agenda". Istituto Affari Internazionali (IAI), Italy, 10, 2017.

[13] Melikoglu M, Webb C. Use of Waste Bread to Produce Fermentation Products. Editors: Webb C, Kosseva M. Elsevier, Food Industry Wastes, 63-76, US, Elsevier, 2013.

[14] Turkiye Cumhuriyeti Toprak Mahsulleri Ofisi. "Ekmegini İsraf Etme: Arastirma Sonuclari 2013". Ankara, Türkiye, 2013.

[15] Artihaber. "Kaçak Fırın Sayısı Şaşırttı". https://www.artihaber27.com/haber/kacak-firin-sayisisasirtti-haberi-536.html (27.05.2018).

[16] Sterman JD. "System dynamics modeling: tools for learning in a complex world". California Management Review, 43(4), 8-25, 2001.

[17] Jittamai P, Kangwansura T. "A hospital admission planning model for operating room allocation under uncertain demand requirements". International Journal of Services and Operations Management, 23(2), 235-256, 2016.

[18] Wong HJ, Morra D, Wu RC, Caesar M, Abrams H. "Using system dynamics principles for conceptual modelling of publicly funded hospitals". Journal of the Operational Research Society, 63(1), 79-88, 2012.

[19] Chen JH, Jan TS. "A system dynamics model of the semiconductor industry development in Taiwan". Journal of the Operational Research Society, 56(10), 1141-1150, 2005.

[20] Chaerul M, Tanaka M, Shekdar AV. "A system dynamics approach for hospital waste management". Waste Management, 28(2), 442-449, 2008.

[21] Ding Z, Yi G, Tam VWY, Huang T. "A system dynamicsbased environmental performance simulation of construction waste reduction management in China". Waste Management, 51, 130-141, 2016.

[22] Cimren E, Bassi A, Fiksel J. "T21-Ohio, a system dynamics approach to policy assessment for sustainable development: a waste to profit case study". Sustainability, 2(9), 2814-2832, 2010.

[23] Akkerman R, Farahani P, Grunow M. "Quality, safety and sustainability in food distribution: a review of quantitative operations management approaches and challenges". Or Spectrum, 32(4), 863-904, 2010.

[24] Van Der Vorst JGAJ, Tromp S, Van DJ, Zee D. "Simulation modelling for food supply chain redesign; Integrated decision making on product quality, sustainability and logistics". International Journal of Production Research, 47(23), 6611-6631, 2009.
[25] Reiner G, Trcka M. "Customized supply chain design: Problems and alternatives for a production company in the food industry. A simulation based analysis". International Journal of Production Economics, 89(2), 217-229, 2004.

[26] Tako AA, Robinson S. "The application of discrete event simulation and system dynamics in the logistics and supply chain context". Decision Support Systems, 52(4), 802-815, 2012.

[27] Georgiadis P, Vlachos D, Iakovou E. "A system dynamics modeling framework for the strategic supply chain management of food chains". Journal of Food Engineering, 70(3), 351-364, 2005.

[28] Minegishi S, Thiel D. "System dynamics modeling and simulation of a particular food supply chain". Simulation Practice and Theory, 8(5), 321-339, 2000.

[29] Barlas Y. "Formal aspects of model validity and validation in system dynamics". System Dynamics Review: The Journal of the System Dynamics Society, 12(3), 183-210, 1996.

[30] Azabagaoglu O, Unakitan G. "Istanbul'da Ekmekcilik Sektoru, Sorunlar ve Cozum Onerileri". Istanbul Ticaret Odasi/Istanbul Dusunce Akademisi, Istanbul, Türkiye, 2018.

[31] Tasci R, Karabak S, Bolat M, Pehlivan A, Şanal T, Oğuz A, Kulen S, Gunes E, Albayrak M. "Ankara ilinde ekmek fırınlarının üretim yapısı ve ekmek israfı". Tarım Ekonomisi Araştırmaları Dergisi, 3(1), 1-16, 2017.

[32] Ertürk A, Arslantaș N, Sarıca D, Demircan V. "Isparta ili kentsel alanda ailelerin ekmek tüketimi ve israfı". Akademik Glda, 13(4), 291-298, 2012.

[33] Tarar OM, UR-RAHMAN S, Din GMU, Murtaza MA. "Studies on the shelf life of bread using acidulants and their salts". Turkish Journal of Biology, 34(2), 133-138, 2010.

[34] Grassmann W. "Warm-up periods in simulation can be detrimental". Probability in the Engineering and Informational Sciences, 22, 415-429, 2008.

[35] Toprak Mahsulleri Ofisi. "Turkiyede ekmek israfi arastirmasi". https://docplayer.biz.tr/29437-Turkiye-deekmek-israfi-arastirmasi.html (25.07.2018).

[36] Turkiye Cumhuriyeti Ticaret Bakanligi. "Türkiye İsraf Raporu". Ankara, Türkiye, 2018.

[37] Griffith R, O'Connell M, Smith K. "Relative prices, consumer preferences, and the demand for food". Oxford Review of Economic Policy, 31(1), 116-130, 2015. 